\title{
Comparison of chlorogenic acid and rutin contents and antioxidant activity of Dendropanax morbiferus extracts according to ethanol concentration
}

\author{
Chung Eun Hwang ${ }^{1}$, Su Cheol $\mathrm{Kim}^{2}$, Chang Soo $\mathrm{Cho}^{3}$, Won Yeong Song ${ }^{4}$, \\ Ok Soo $\mathrm{Joo}^{2 *}$, Kye Man $\mathrm{Cho}^{2 *}$ \\ ${ }^{1}$ Department of Research \& Development, Jinju Bio Industry Foundation, Jinju 52839, Korea \\ ${ }^{2}$ Department of Food Science, Gyeonnam National University of Science and Technology, Jinju 52725, Korea \\ ${ }^{3}$ HyurimHwangchil Corporation, Jinju 52839, Korea \\ ${ }^{4}$ Department of Food Nutrition, International University of Korea, Jinju 52833, Korea
}

\section{주정 농도에 따른 황칠나무(Dendropanax morbiferus) 부위별 클로로젠산 및 루틴 함량과 항산화 활성 비교}

\author{
황정은 $^{1} \cdot$ 김수철 $^{2} \cdot$ 조창수 $^{3} \cdot$ 송원영 $^{4} \cdot$ 주옥수 $^{2} *$. 조계만 ${ }^{2} *$ \\ ${ }^{1}$ (재)진주바이오산업진흥원 연구개발실, ${ }^{2}$ 경남과학기술대학교 식품과학과, \\ 3농업회사법인 휴림황칠(주), ${ }^{4}$ 한국국제대학교 식품영양학과
}

\begin{abstract}
This study investigated the phenolics (TP) and phytochemical contents and radical-scavenging activity of ethanol extracts of Dendropanax morbiferus parts (leaf, stem, and root). The contents of chlorogenic acid (CA) and rutin (RT) and radical-scavenging activity of all extracts by parts were in the order of leaf, stem and root. In the case of leaf, the TP contents were $\mathbf{2 . 1 5}-2.52 \mathrm{mg} / \mathrm{g}$ when extracted with hot water and ethanol concentration (30-70\%), and there was no difference depending on extraction solvents and times. However, $95 \%$ alcohol extracts showed the lowest content of TP (extraction time: $2-4 \mathrm{~h}$ ). Particularly, CA and RT contents of 70\% ethanolic extract for $2 \mathrm{~h}$ were the highest as $12.33 \mathrm{mg} / \mathrm{g}$ and $14.01 \mathrm{mg} / \mathrm{g}$, respectively, in which DPPH and ABTS radical scavenging activities were also highest $(85 \%$ and $110 \%)$, respectively.
\end{abstract}

Key words : Dendropanax morbiferus, water and ethanol extracts, antioxidant, chlorogenic acid, rutin

서 론

황칠나무(Dendropanax morbifera)는 두릅나무과에 속하 고, 아열대성 상록교목으로 전 세계에서 유일하게 한국에서만 자생하는 나무로 알려져 있다. 황칠나무의 학명에서 dendro 는 나무란 뜻이며, panax는 만병통치의 뜻을 가지며, 특히 morbifera는 병을 내쫓다는 뜻을 가지고 있어 예부터 인삼나 무로도 불리우고 있다. 황칠나무의 황색 수액은 고급도료로 사 용되어 왔으며, 민간에서는 잎을 우려내 차로 음용해왔다 (Lee 등, 2019). 황칠의 효능과 관련된 연구는 황칠의 미백 효과(Lim 등, 1998), 생체 방어체계 강화(Park 등, 2004), 항산화(Hyun 등, 2013), 항당뇨(An 등, 2014) 효능 등이 비

*Corresponding author. Ok Soo Joo. osjoo@gntech.ac.kr, Phone :+82-55-751-3273, Fax : +82-55-751-3279

Kye Man Cho. E-mail : kmcho@gntech.ac.kr, Phone: +82-55-751-3272, Fax : +82-55-751-3279

Received 02 November 2020; Revised 03 December 2020; Accepted 08 December 2020.

Copyright (c) The Korean Society of Food Preservation.

This is an Open Access article distributed under the terms of the Creative Commons Attribution Non-Commercial License (http://creativecommons.org/licenses/by-nc/4.0) which permits unrestricted non-commercial use, distribution, and reproduction in any medium, provided the original work is properly cited. 
교적 최근에 보고되었다.

다양한 생리활성 물질 중 항산화, 항암, 항균활성 등에 효능 을 나타내는 천연물질로는 식물의 정유성분, 색소, flavonoid 화합물과 같은 phytochemical 등이 보고되었다(Lee 등, 2015). 특히, 현재까지 우리나라에서 식용과 약용으로 이용되어 온 식물 중 마늘, 생강, 양파, 고추, 뽕나무, 상산나무, 인삼 등은 대부분 표준물질과 그 효능에 관한 연구가 많이 보고된 상태이 다(Chae 등, 1999; Chung 등, 1999; Kim 등, 2006; Jang 등, 2014; Yoo 등, 2005). 한편, 황칠나무의 경우에도 chlorogenic acid 및 rutin과 같은 flavonoid 성분이 존재함을 Youn 등 (2018)이 최근에 보고하였으나 본 연구를 진행하기 위해 관련 된 국내 연구 결과들을 조사한 결과에 의하면 아직까지는 황 칠에 관한 연구가 많이 부족한 것으로 사료된다. 이에 본 연 구자들은 소재가 희귀하고 잠재적 효능이 많을 것으로 판단 되는 황칠나무 연구를 진행하기에 이르렀다. 이에 따라 본 연 구자들은 황칠나무 부위(잎, 줄기, 뿌리)에 따른 flavonoid 성 분 중 항산화 효능 등이 우수한 성분으로 알려진 chlorogenic aicd와 rutin을 황칠나무의 지표물질로 선정하였다.

따라서 본 연구에서는 황칠 잎, 줄기, 뿌리를 따로 구분하 여 열수와 발효주정 $(30,50,70,95 \%)$, 추출시간에 따른 chlorogenic acid와 rutin 함량 비교분석 및 항산화 활성을 측 정하여 황칠 원료 추출물에 대한 기초자료 확보를 위해 수행 하였다.

\section{재료 및 방법}

\section{실험재료 및 시약}

황칠나무(잎, 줄기, 뿌리)는 경남 하동군 소재지에서 재배 되고 있는 것을 농업회사법인 휴림황칠(주로부터 제공받았으 며 부위별 생산 시기는 잎의 경우 1 년, 줄기는 5 년, 뿌리는 15 년이 된 것을 본 연구에 사용하였다. 황칠나무의 chlorogenic acid 및 rutin은 Sigma-Aldrich (Saint Louis, MO, USA)에서 구입하였다. 항산화 활성 측정에 사용한 시약 중 2,4,6azino-bis(3-ethylbenzthiazoline-6-sulphnoic acid)(ABTS) 및 2,2-diphenyl-1-picrydrazyl(DPPH) 역시 Sigma-Aldrich에서 구 입하여 사용하였다. Methanol, acetonitrile, formic acid, water 및 acetic acid 등의 시약 및 유기 용매는 J.T.Baker사 (Philipsbug, NJ, USA)에서 구입하여 사용하였으며, 그 외 기 타 시약은 필요에 따라서 분석용 1 급 또는 특급 시약을 구입 하여 사용하였다.

\section{분석기기}

Chlorogenic acid(CA) 및 rutin(RT) 분석은 high performance liquid chromatography(HPLC, Agilent 1200 system,
Boeblingen, Germany)를 사용하였으며, 라디칼 소거활성 (1,1-diphenyl-2-picrylhydrazyl，DPPH 및 2,2'-azino-bis(3ethylbenzothiazoline-6-sulfonic acid, ABTS)) 측정은 Spectrophotometer(Mega-800, Scinco, Seoul, Korea)를 사용하였다.

\section{황칠나무의 부위별(잎, 줄기, 뿌리) 추출물 제조}

추출물 제조 전 황칠나무 잎, 줄기, 뿌리는 각각 믹서기에 곱게 분쇄하여 분말형태로 준비하였다. 열수추출물 제조는 분 말 $10 \mathrm{~g}$ 에 HPLC 등급의 water $200 \mathrm{~mL}$ 를 가하고, $80^{\circ}$ 로 설정 된 환류냉각장치에서 각 시료들은 2 시간과 4 시간씩 1 회 추출 을 실시하였다. 주정 추출 역시 상기와 같은 방법으로 30,50 , $70,95 \%$ 발효주정 $200 \mathrm{~mL}$ 를 가하여 환류냉각장치로 추출을 진행하였다. 황칠나무 부위별 추출이 끝난 후에는 감압조건에 서 추출물 $(50 \mathrm{mg} / \mathrm{mL})$ 을 여과하여 본 연구에 사용하였다.

\section{$\mathrm{pH}$, 산도 및 total phenolics 함량 측정}

$\mathrm{pH}$ 측정은 황칠 부위별 추출물 $1 \mathrm{~mL}$ 를 취하여 $\mathrm{pH}$ 미터기 (MP 220, Mettler Toledo, Bern, Switzerland)로 측정하였고, 산도는 증류수 $49 \mathrm{~mL}$ 와 각각의 추출물 $(1 \mathrm{~mL})$ 를 첨가하고, $0.1 \mathrm{~N} \mathrm{NaOH}$ 용액으로 중화 적정하여 최종적으로는 lactic acid로 환산하여 백분율로 나타내었다. Total phenolics 함량 은 널리 알려져 있는 Folin-Denis법을 Hwang 등(2018)의 논 문에 따라 수행하였다. 각 추출물 $500 \mu \mathrm{L}$ 를 시험관에 분주하 고, $25 \%$ 탄산나트륨 $\left(\mathrm{Na}_{2} \mathrm{CO}_{3}\right)$ 용액 $500 \mu \mathrm{L}$ 를 첨가하고 3분 간 1차 반응시켰다. 1차 반응 후 $2 \mathrm{~N}$ Folin-Ciocalteu phenol 시약을 $250 \mu \mathrm{L}$ 첨가하여 $37^{\circ} \mathrm{C}$ 에서 1 시간 발색반응을 진행하 였다. 발색된 청색 반응물은 3 분간 $13,500 \mathrm{rpm}$ 속도로 원심 분리(Micro 12, Hanil Science Co., Ltd., Seoul, Korea)하여 상등액만을 회수하여 spectrophotometer(732 nm)로 측정하 였다. Total phenolic 함량 계산은 gallic acid를 이용하여 작 성된 표준 검량곡선으로부터 함량 $(\mathrm{mg} / \mathrm{g})$ 을 산출하였다.

\section{Chlorogenic acid 및 rutin 함량 분석}

Flavonol 배당체 분석은 HPLC로 정량 분석하였다. Column 은 Eclipse Plus $\mathrm{C}_{18}(5 \mu \mathrm{m}, 4.6 \times 250 \mathrm{~mm})$ 을 사용하였으며, 이 동상 용매 $\mathrm{A}(0.1 \%$ formic acid in water $)$ 와 $\mathrm{B}(0.1 \%$ formic acid in $90 \%$ acetonitrile)로 구성하여 분석을 수행하였다. 각 용매 gradient 조건은 A 용매를 기준으로 $100 \%(0$ 분 $), 90 \%(4$ 분), $40 \%$ (20분), $90 \%$ (23-30분)로 유지하였다. 각 샘플의 주 입량은 $20 \mu \mathrm{L}$, 이동상 속도는 $30^{\circ} \mathrm{C}$ 에서 분당 $1 \mathrm{~mL}$ 의 유속을 유지하여 $310 \mathrm{~nm}$ 의 diode array detector (DAD)에서 검출하 였다. 한편, chlorogenic acid와 rutin 표준품은 HPLC-grade water를 용매로 사용하여 $0.25,0.50,0.75,0.95,1.00 \mathrm{mg} / \mathrm{g}$ 의 농도로 제조하여 검량선을 작성하여 아래의 식에 대입하여 
$\mathrm{mg} / \mathrm{g}$ 으로 함량을 표기하였다.

Chlorogenic acid: $y=52007 x-239.10\left(R^{2}=0.9998\right)$

Rutin: $y=10820 x-265.26\left(R^{2}=0.9979\right)$

\section{라디칼 소거활성 측정}

DPPH 및 ABTS 라디칼 소거활성은 Hwang 등(2018)의 논 문을 약간 변형하여 수행하였다. DPPH 라디칼 소거활성은 각 각의 추출물 $(50 \mathrm{mg} / \mathrm{mL}) 100 \mu \mathrm{L}$ 를 96-well plate에 분주하고, $\mathrm{DPPH}\left(0.5 \mathrm{mM}\right.$ in etahnol) 용액 $50 \mu \mathrm{L}$ 를 가하여 상온( $\left.25^{\circ} \mathrm{C}\right)$ 에 서 15 분간 반응시켜 $517 \mathrm{~nm}$ 에서 흡광도를 측정하였다.

$\mathrm{ABTS}$ 라디칼 소거능은 $7 \mathrm{mM} \mathrm{ABTS} \mathrm{용액}(5.0 \mathrm{~mL})$ 과 140 $\mathrm{mM}$ 의 potassium persulphate $(88 \mu \mathrm{L})$ 를 혼합하여 $12-16$ 시간 동안 암실에서 $\mathrm{ABTS}$ 양이온을 형성시켰다. 이후 $414 \mathrm{~nm}$ 에 서 흡광도의 값이 $1.5 \pm 0.02$ 가 되도록 phosphate buffer saline (PBS)로 조정하고, 조정된 $\mathrm{ABTS}$ 용액 $190 \mu \mathrm{L}$ 에 각각의 추 출물 $(50 \mathrm{mg} / \mathrm{mL}) 10 \mu \mathrm{L}$ 를 가하여 6분간 반응시키고 $734 \mathrm{~nm}$
에서 측정하였다. $\mathrm{DPPH}$ 및 $\mathrm{ABTS}$ 라디칼 소거활성의 대조 구는 모두 PBS로 대체하였으며, 아래 식에 따라 백분율로 나 타내었다.

소거활성 $(\%)=(1-$ 음성대조구 / 첨가구 흡광도 $) \times 100$

\section{통계처리}

각 실험은 3 회 반복 수행하였으며, 본 결과는 SPSS 12.0 packae 시스템으로 분산 분석을 실시하였으며, Duncan's의 다범위검정을 이용하여 조건별 유의차를 나타내었다.

\section{결과 및 고찰}

\section{황칠나무 부위별 추출물의 $\mathrm{pH}$, 산도, total phenolics 함량 비교}

황칠 잎, 줄기, 뿌리 추출 용매와 시간을 달리한 추출물의 $\mathrm{pH}$, 산도, total phenolics 함량 비교는 Table 1에 나타내었다.

Table 1. Comparison of pH and acidity and total phenolics content of Dendropanax morbiferus extracts according to ethanol concentraction

\begin{tabular}{|c|c|c|c|c|c|c|c|c|c|}
\hline \multirow{3}{*}{$\begin{array}{c}\text { Extraction } \\
\text { concentration/time (h) }\end{array}$} & \multicolumn{9}{|c|}{ Comparison index $(\mathrm{DW})^{1)}$} \\
\hline & \multicolumn{3}{|c|}{ Leaf } & \multicolumn{3}{|c|}{ Stem } & \multicolumn{3}{|c|}{ Root } \\
\hline & $\mathrm{pH}$ & Acidity & $\mathrm{TP}(\mathrm{mg} / \mathrm{g})^{2)}$ & $\mathrm{pH}$ & Acidity & $\mathrm{TP}(\mathrm{mg} / \mathrm{g})$ & $\mathrm{pH}$ & Acidity & $\mathrm{TP}(\mathrm{mg} / \mathrm{g})$ \\
\hline \multicolumn{10}{|l|}{ Water } \\
\hline 2 & $8.06 \pm 0.48^{\mathrm{a} 3)}$ & $0.06 \pm 0.00^{\mathrm{b}}$ & $2.17 \pm 0.11^{\mathrm{a}}$ & $9.26 \pm 0.56^{\mathrm{a}}$ & $0.03 \pm 0.00^{\mathrm{b}}$ & $0.18 \pm 0.01^{\mathrm{b}}$ & $6.36 \pm 0.38^{\mathrm{a}}$ & $0.54 \pm 0.03^{\mathrm{e}}$ & $0.09 \pm 0.00^{\mathrm{b}}$ \\
\hline 4 & $8.98 \pm 0.54^{\mathrm{a}}$ & $0.05 \pm 0.00^{\mathrm{b}}$ & $2.29 \pm 0.11^{\mathrm{a}}$ & $9.25 \pm 0.56^{\mathrm{a}}$ & $0.08 \pm 0.00^{\mathrm{b}}$ & $0.34 \pm 0.02^{\mathrm{a}}$ & $5.99 \pm 0.36^{\mathrm{a}}$ & $0.56 \pm 0.03^{\mathrm{e}}$ & $0.19 \pm 0.01^{\mathrm{b}}$ \\
\hline \multicolumn{10}{|l|}{$30 \%$ Fermented alcohol } \\
\hline 2 & $7.16 \pm 0.43^{b}$ & $0.03 \pm 0.00^{\mathrm{b}}$ & $2.50 \pm 0.13^{\mathrm{a}}$ & $7.25 \pm 0.44^{\mathrm{c}}$ & $0.04 \pm 0.00^{\mathrm{b}}$ & $0.15 \pm 0.01^{\mathrm{b}}$ & $6.31 \pm 0.38^{\mathrm{a}}$ & $0.80 \pm 0.05^{\mathrm{d}}$ & $0.09 \pm 0.00^{\mathrm{b}}$ \\
\hline 4 & $7.58 \pm 0.45^{\mathrm{b}}$ & $0.03 \pm 0.00^{\mathrm{b}}$ & $2.52 \pm 0.13^{\mathrm{a}}$ & $7.78 \pm 0.47^{\mathrm{c}}$ & $0.05 \pm 0.00^{\mathrm{b}}$ & $0.14 \pm 0.01^{\mathrm{b}}$ & $6.19 \pm 0.37^{\mathrm{a}}$ & $0.80 \pm 0.05^{\mathrm{d}}$ & $0.17 \pm 0.01^{\mathrm{b}}$ \\
\hline \multicolumn{10}{|l|}{$50 \%$ Fermented alcohol } \\
\hline 2 & $6.54 \pm 0.39^{c}$ & $0.06 \pm 0.00^{\mathrm{b}}$ & $2.49 \pm 0.12^{\mathrm{a}}$ & $7.01 \pm 0.42^{\mathrm{c}}$ & $0.07 \pm 0.00^{\mathrm{b}}$ & $0.39 \pm 0.02^{\mathrm{a}}$ & $5.32 \pm 0.32^{\mathrm{b}}$ & $1.05 \pm 0.06^{\mathrm{c}}$ & $0.23 \pm 0.01^{\mathrm{a}}$ \\
\hline 4 & $6.56 \pm 0.39^{c}$ & $0.06 \pm 0.00^{\mathrm{b}}$ & $2.49 \pm 0.12^{\mathrm{a}}$ & $7.69 \pm 0.46^{\mathrm{c}}$ & $0.08 \pm 0.00^{\mathrm{b}}$ & $0.39 \pm 0.02^{\mathrm{a}}$ & $5.65 \pm 0.34^{b}$ & $1.00 \pm 0.06^{\mathrm{c}}$ & $0.27 \pm 0.01^{\mathrm{a}}$ \\
\hline \multicolumn{10}{|l|}{$70 \%$ Fermented alcohol } \\
\hline 2 & $6.66 \pm 0.40^{\mathrm{c}}$ & $0.09 \pm 0.01^{\mathrm{a}}$ & $2.49 \pm 0.12^{\mathrm{a}}$ & $8.36 \pm 0.50^{\mathrm{b}}$ & $0.07 \pm 0.00^{\mathrm{b}}$ & $0.29 \pm 0.01^{\mathrm{a}}$ & $4.48 \pm 0.27^{\mathrm{c}}$ & $1.19 \pm 0.07^{\mathrm{b}}$ & $0.14 \pm 0.01^{b}$ \\
\hline 4 & $6.98 \pm 0.42^{\mathrm{c}}$ & $0.09 \pm 0.01^{\mathrm{a}}$ & $2.15 \pm 0.11^{\mathrm{a}}$ & $8.26 \pm 0.50^{\mathrm{b}}$ & $0.08 \pm 0.00^{\mathrm{b}}$ & $0.30 \pm 0.02^{\mathrm{a}}$ & $4.12 \pm 0.25^{\mathrm{c}}$ & $1.15 \pm 0.07^{\mathrm{b}}$ & $0.29 \pm 0.01^{\mathrm{a}}$ \\
\hline \multicolumn{10}{|l|}{$95 \%$ Fermented alcohol } \\
\hline 2 & $5.06 \pm 0.30^{\mathrm{d}}$ & $1.03 \pm 0.06^{\mathrm{a}}$ & $1.06 \pm 0.05^{\mathrm{b}}$ & $4.36 \pm 0.26^{\mathrm{d}}$ & $1.09 \pm 0.07^{\mathrm{a}}$ & $0.31 \pm 0.02^{\mathrm{a}}$ & $3.19 \pm 0.19^{\mathrm{d}}$ & $1.36 \pm 0.08^{\mathrm{a}}$ & $0.22 \pm 0.01^{\mathrm{a}}$ \\
\hline 4 & $5.55 \pm 0.33^{\mathrm{d}}$ & $1.08 \pm 0.06^{\mathrm{a}}$ & $1.06 \pm 0.05^{\mathrm{b}}$ & $4.68 \pm 0.28^{\mathrm{d}}$ & $1.10 \pm 0.07^{\mathrm{a}}$ & $0.32 \pm 0.02^{\mathrm{a}}$ & $3.36 \pm 0.20^{\mathrm{d}}$ & $1.52 \pm 0.09^{\mathrm{a}}$ & $0.08 \pm 0.00^{\mathrm{b}}$ \\
\hline
\end{tabular}

${ }^{1)}$ All values are presented as the mean \pm SD of triplicate determination (dry weight).

${ }^{2)}$ Total phenolics.

${ }^{3)}$ All values within a column with different superscript letters are significantly different from each other at $\mathrm{p}<0.05$ by Duncan's multiple range test. 
황칠 잎 추출물의 $\mathrm{pH}$ 는 열수추출물이 추출 2 시간과 4 시간 후에 각각 8.06 및 8.98 로 다른 추출물에 비해 수치가 가장 높았으며 모든 추출물에서 $\mathrm{pH}$ 는 추출 시간이 증가할수록 약 간 증가하는 것으로 나타났다. $30 \%$ 발효주정 추출물의 경우 에는 7.16(2시간)-7.58(4시간), $50 \%$ 발효주정 추출물의 경우 6.54(2시간)-6.56(4시간), $70 \%$ 발효주정 추출물의 경우 6.66 (2 시간)-6.98(4시간), 95\% 발효주정 추출물은 5.06(2시간)-5.55 (4시간) 수준으로 나타났으며, 발효주정의 농도가 증가할수 록 $\mathrm{pH}$ 범위는 조금씩 낮아지는 경향을 보였으나 크게 감소하 지는 않았다. 한편, 황칠 줄기 추출물의 경우 역시 열수추출 물이 발효주정 추출물에 비해 $\mathrm{pH}$ 가 9 로 높았으며, 30,50 , $70 \%$ 발효주정의 경우 $\mathrm{pH}$ 범위가 7-8 수준으로 유사하였으 나, $95 \%$ 발효주정 추출물의 경우에는 추출 2 시간과 4 시간째 각각 4.36-4.68로 급격히 감소하였다. 황칠 뿌리 추출물의 경 우도 황칠 잎과 줄기 추출물과 유사한 경향으로 $\mathrm{pH}$ 는 열수추 출물과 $30 \%$ 발효주정 추출물에서 5.99-6.36으로 가장 높았 고 발효 주정 농도가 증가할수록 $\mathrm{pH}$ 는 감소하여 $95 \%$ 발효주 정 추출물은 추출 2 시간과 4 시간째 각각 3.19 와 3.36 으로 급 격히 감소하였다. 황칠 잎, 줄기, 뿌리 추출물의 산도 변화는 추출 시간에 따른 변화는 없었으나, 잎, 줄기, 뿌리 추출물의 경우 주정 농도가 $50 \%$ 에서 $95 \%$ 로 증가할수록 산도는 조금 씩 증가하였고 $95 \%$ 발효주정 뿌리 추출물에서 추출 2시간과 4시간째 각각 1.36 및 $1.52 \%$ 로 가장 높았다. Total phenolic 함량은 황칠 잎 열수 추출물의 경우 추출 2시간째 $2.17 \mathrm{mg} / \mathrm{g}$ 에서 4시간째 $2.29 \mathrm{mg} / \mathrm{g}$ 으로 아주 약간 증가했지만 유의적 차이는 없었다. $30 \%$ 발효주정 잎 추출물 역시 $2.50 \mathrm{mg} / \mathrm{g}$ (추 출 2시간) 및 $2.52 \mathrm{mg} / \mathrm{g}$ (추출 4시간)이었고, $50 \%$ 와 $70 \%$ 발 효주정 추출물 역시 $2.15 \mathrm{mg} / \mathrm{g}$ 에서 $2.49 \mathrm{mg} / \mathrm{g}$ 으로 유사한 함 량을 나타내었다. $95 \%$ 발효주정 추출물에서는 $1.06 \mathrm{mg} / \mathrm{g}$ 으 로 열수와 $30-70 \%$ 발효주정 추출물에 비해 낮은 함량을 나 타내었다. 한편, 황칠 줄기와 뿌리에서는 열수와 발효주정 추 출에 따른 차이는 나타나지 않았고, 잎 추출물에 비해 그 함 량은 현저히 낮았으며 전체적으로 TPC 함량은 잎 > 줄기 > 뿌리 순으로 나타났다.

천연물에 대부분 함유되어있는 항산화성 물질인 폴리페놀 및 플라보노이드 화합물들은 항산화뿐 아니라, 피부질환 예 방효과도 있는 것으로 보고되었다(Park과 Han, 2016). 특히, Park과 Han(2016)의 황칠나무 잎 추출물에서는 폴리페놀 함 량은 $74.08 \mathrm{mg} / \mathrm{g}$, 총 플라보노이드는 $97.36 \mathrm{mg} / \mathrm{g}$ 으로 보고하 였고, 이는 본 연구에서의 황칠 잎(열수 및 주정) 추출물에서 의 함량 차이가 크게 나타났다. 이는 Park과 $\operatorname{Han}(2016)$ 은 $70 \%$ 메탄올을 사용하여 초음파 분쇄를 통해 72 시간 추출하 고, 용매 제거 후 동결 건조한 시료를 대상으로 폴리페놀 및 플라보노이드 함량을 측정했음으로 본 연구방법과 함량 차이
가 크게 나타나는 것으로 판단된다. 따라서 같은 천연물이라 도 추출 용매와 추출 시간, 각 시료들의 전처리 상태(휘발성 용매 제거 등)에 따라 여러 상이한 결과가 도출되는 것으로 사료된다.

\section{황칠나무 부위별 추출물의 chlorogenic acid(CA) 및 rutin (RT) 함량 비교}

황칠 부위별(잎, 줄기, 뿌리) 열수와 발효주정 추출물의 $\mathrm{CA}$ 와 RT 함량을 분석한 결과는 Table 2 와 Fig. 1 에 나타내 었다. 황칠 잎 추출물 중 열수추출에서 $\mathrm{CA}$ 는 추출 2 시간째 $7.06 \mathrm{mg} / \mathrm{g}$ 이었고, 4시간째에는 $6.98 \mathrm{mg} / \mathrm{g}$ 으로 추출 시간에 따라 함량이 증가하거나 감소하는 변화는 없었다(Table 1). RT 역시 추출 2시간 $(12.16 \mathrm{mg} / \mathrm{g})$ 과 4시간 $(12.44 \mathrm{mg} / \mathrm{g})$ 함량 은 유사하였다. 황칠 잎 $30 \%$ 발효주정 추출의 경우 $\mathrm{CA}$ 는 추 출 2시간(Fig. 1A)과 4시간째 각각 4.42-4.27 mg/g으로 열수 추출에 비해 낮은 함량이 검출되었다. $50 \%$ 발효주정 추출 역 시 2시간째 $4.56 \mathrm{mg} / \mathrm{g}$ 이었고(Fig. $1 \mathrm{~B}$ ), 추출 4시간째 6.60 $\mathrm{mg} / \mathrm{g}$ 으로 함량에 큰 차이는 나타나지 않았다. 그러나 $70 \%$ 발효주정 추출물에서는 추출 2시간째 $12.33 \mathrm{mg} / \mathrm{g}$ 으로 열수 추출과 발효주정 $30 \%$ 와 $50 \%$ 에 비해 증가하는 경향을 보였 다(Fig. 1C). 그러나 추출 4시간째에는 $5.53 \mathrm{mg} / \mathrm{g}$ 으로 감소하 였다. $95 \%$ 발효주정 추출물은 추출 2 시간과 4 시간째 1.11 $\mathrm{mg} / \mathrm{g}$ 과 $2.01 \mathrm{mg} / \mathrm{g}$ 이 검출되었으며, $95 \%$ 발효주정에서는 CA 와 RT가 거의 용출되지 않는 것으로 사료된다(Fig. 1D). RT 는 $95 \%$ 발효주정 추출을 제외하고 열수와 모든 발효주정 추 출물에서 비교적 많은 양이 용출되는 것으로 결과가 도출되 었다. 황칠 잎 열수추출물의 경우 추출 2시간째 RT 함량은 $12.16 \mathrm{mg} / \mathrm{g}$ 이었고 $30 \%$ 발효주정의 경우 추출 2 시간째 14.60 $\mathrm{mg} / \mathrm{g}, 50 \%$ 발효주정의 경우 $11.71 \mathrm{mg} / \mathrm{g}, 70 \%$ 발효주정 추 출물에서는 $14.09 \mathrm{mg} / \mathrm{g}$ 으로 가장 많은 양이 검출되었다 (Table 2). 한편, 황칠 줄기와 뿌리의 경우에는 잎 열수와 발 효주정 추출물에 비해 월등히 낮은 함량을 보였으며, 이를 통 해 황칠 잎에는 CA와 RT가 풍부하게 함유되어 있으나, 줄기 와 뿌리의 경우에는 그렇지 않은 것으로 판단된다.

황칠나무에는 chlorogenic $\operatorname{acid}(\mathrm{CA})$ 와 rutin(RT)과 같은 성분이 함유되어 있는 것으로 알려져 있다(Hyun 등, 2013). Youn 등(2018)의 황칠나무 추출물 연구에서는 황칠 잎의 경 우 CA와 RT가 검출되었는데, $\mathrm{CA}$ 보다 RT 함량이 약 5 배 이 상 많은 것으로 보고하였다. 본 연구 또한 이 추출물의 경우 5 배 이상 함량 차이가 나지는 않았으나, 전반적으로 CA보다 는 RT 함량이 좀 더 많은 것으로 나타나 Youn 등(2018)의 결과와 유사한 것으로 판단된다. 또한, Youn 등(2018)은 주 정(추출용매)의 비율이 높을수록 CA 및 RT 성분이 많이 용 출되는 것으로 보고하였고, 이는 $70 \%$ 주정에서 추출 2 시간 
Table 2. Comparison of chlorogenic acid and rutin contents of Dendropanax morbiferus extract according to ethanol concentration

\begin{tabular}{|c|c|c|c|c|c|c|c|c|c|}
\hline \multirow{3}{*}{$\begin{array}{c}\text { Extraction } \\
\text { concentration/time }(\mathrm{h})\end{array}$} & \multicolumn{9}{|c|}{ Contents $(\mathrm{mg} / \mathrm{g} \mathrm{DW})^{1)}$} \\
\hline & \multicolumn{3}{|c|}{ Leaf } & \multicolumn{3}{|c|}{ Stem } & \multicolumn{3}{|c|}{ Root } \\
\hline & $\mathrm{CA}^{2)}$ & $\mathrm{RT}^{3)}$ & $\mathrm{TC}^{4)}$ & $\mathrm{CA}$ & RT & $\mathrm{TC}$ & $\mathrm{CA}$ & RT & $\mathrm{TC}$ \\
\hline \multicolumn{10}{|l|}{ Water } \\
\hline 2 & $7.06 \pm 0.35^{\mathrm{b} 5)}$ & $12.16 \pm 0.61^{\mathrm{b}}$ & $19.22 \pm 0.96^{\mathrm{b}}$ & $1.31 \pm 0.07^{\mathrm{c}}$ & $1.33 \pm 0.07^{\mathrm{a}}$ & $2.64 \pm 0.13^{\mathrm{c}}$ & $0.15 \pm 0.01^{\mathrm{d}}$ & $0.50 \pm 0.03^{\mathrm{b}}$ & $0.65 \pm 0.03^{\mathrm{e}}$ \\
\hline 4 & $6.98 \pm 0.35^{\mathrm{b}}$ & $12.44 \pm 0.62^{\mathrm{b}}$ & $19.42 \pm 0.97^{\mathrm{b}}$ & $1.25 \pm 0.06^{\mathrm{c}}$ & $0.80 \pm 0.04^{\mathrm{b}}$ & $2.05 \pm 0.10^{\mathrm{d}}$ & $0.21 \pm 0.01^{\mathrm{c}}$ & $0.59 \pm 0.03^{\mathrm{b}}$ & $0.80 \pm 0.04^{\mathrm{d}}$ \\
\hline \multicolumn{10}{|l|}{$30 \%$ Fermented alcohol } \\
\hline 2 & $4.42 \pm 0.22^{\mathrm{d}}$ & $14.60 \pm 0.73^{\mathrm{a}}$ & $19.02 \pm 0.95^{\mathrm{b}}$ & $1.91 \pm 0.10^{\mathrm{b}}$ & $0.84 \pm 0.04^{\mathrm{b}}$ & $2.75 \pm 0.14^{\mathrm{b}}$ & $1.21 \pm 0.06^{\mathrm{a}}$ & $0.80 \pm 0.04^{\mathrm{a}}$ & $2.01 \pm 0.10^{\mathrm{a}}$ \\
\hline 4 & $4.27 \pm 0.21^{\mathrm{d}}$ & $14.38 \pm 0.72^{\mathrm{a}}$ & $18.65 \pm 0.93^{\mathrm{c}}$ & $1.83 \pm 0.09^{\mathrm{b}}$ & $0.85 \pm 0.04^{\mathrm{b}}$ & $2.68 \pm 0.13^{\mathrm{b}}$ & $1.19 \pm 0.06^{\mathrm{a}}$ & $0.80 \pm 0.04^{\mathrm{a}}$ & $1.99 \pm 0.10^{\mathrm{a}}$ \\
\hline \multicolumn{10}{|l|}{$50 \%$ Fermented alcohol } \\
\hline 2 & $4.56 \pm 0.23^{\mathrm{d}}$ & $11.71 \pm 0.59^{\mathrm{b}}$ & $16.27 \pm 0.81^{\mathrm{e}}$ & $2.01 \pm 0.10^{\mathrm{c}}$ & $0.76 \pm 0.04^{\mathrm{c}}$ & $2.77 \pm 0.14^{\mathrm{b}}$ & $0.73 \pm 0.04^{\mathrm{c}}$ & $0.52 \pm 0.03^{\mathrm{b}}$ & $1.25 \pm 0.06^{\mathrm{c}}$ \\
\hline 4 & $6.60 \pm 0.33^{\mathrm{b}}$ & $10.61 \pm 0.53^{\mathrm{c}}$ & $17.21 \pm 0.86^{\mathrm{d}}$ & $2.62 \pm 0.13^{\mathrm{b}}$ & $0.85 \pm 0.04^{\mathrm{b}}$ & $3.47 \pm 0.17^{\mathrm{a}}$ & $0.95 \pm 0.05^{\mathrm{b}}$ & $0.50 \pm 0.03^{\mathrm{b}}$ & $1.45 \pm 0.07^{\mathrm{b}}$ \\
\hline \multicolumn{10}{|l|}{$70 \%$ Fermented alcohol } \\
\hline 2 & $12.33 \pm 0.62^{\mathrm{a}}$ & $14.09 \pm 0.12^{\mathrm{a}}$ & $26.42 \pm 0.17^{\mathrm{a}}$ & $2.39 \pm 0.12^{\mathrm{a}}$ & $0.73 \pm 0.04^{\mathrm{c}}$ & $3.12 \pm 0.16^{\mathrm{a}}$ & $0.13 \pm 0.01^{\mathrm{d}}$ & $0.49 \pm 0.02^{\mathrm{b}}$ & $0.62 \pm 0.03^{\mathrm{e}}$ \\
\hline 4 & $5.53 \pm 0.28^{\mathrm{c}}$ & $10.69 \pm 0.20^{\mathrm{c}}$ & $16.22 \pm 0.30^{\mathrm{e}}$ & $1.35 \pm 0.07^{\mathrm{c}}$ & $0.78 \pm 0.04^{\mathrm{c}}$ & $2.13 \pm 0.11^{\mathrm{d}}$ & $0.12 \pm 0.01^{\mathrm{d}}$ & $0.50 \pm 0.03^{\mathrm{b}}$ & $0.62 \pm 0.03^{\mathrm{e}}$ \\
\hline \multicolumn{10}{|l|}{ 95\% Fermented alcohol } \\
\hline 2 & $1.11 \pm 0.06^{\mathrm{f}}$ & $2.33 \pm 0.12^{\mathrm{e}}$ & $3.44 \pm 0.17^{\mathrm{g}}$ & $0.36 \pm 0.02^{\mathrm{e}}$ & $0.59 \pm 0.03^{\mathrm{d}}$ & $0.95 \pm 0.05^{\mathrm{f}}$ & $0.10 \pm 0.01^{\mathrm{d}}$ & $0.49 \pm 0.02^{\mathrm{b}}$ & $0.59 \pm 0.03^{\mathrm{e}}$ \\
\hline 4 & $2.01 \pm 0.10^{\mathrm{e}}$ & $3.91 \pm 0.20^{\mathrm{d}}$ & $5.92 \pm 0.30^{\mathrm{f}}$ & $0.56 \pm 0.03^{\mathrm{d}}$ & $0.80 \pm 0.04^{\mathrm{b}}$ & $1.36 \pm 0.07^{\mathrm{e}}$ & $0.10 \pm 0.01^{\mathrm{d}}$ & $0.50 \pm 0.03^{\mathrm{b}}$ & $0.60 \pm 0.03^{\mathrm{e}}$ \\
\hline
\end{tabular}

${ }^{1)}$ All values are presented as the mean $\pm \mathrm{SD}$ of triplicate determination. (dry weight).

${ }^{2)}$ Chlorogenic acid.

${ }^{3)}$ Rutin.

${ }^{4)}$ Total content

${ }^{5)}$ All values within a column with different superscript letters are significantly different from each other at $\mathrm{p}<0.05$ by Duncan's multiple range test.
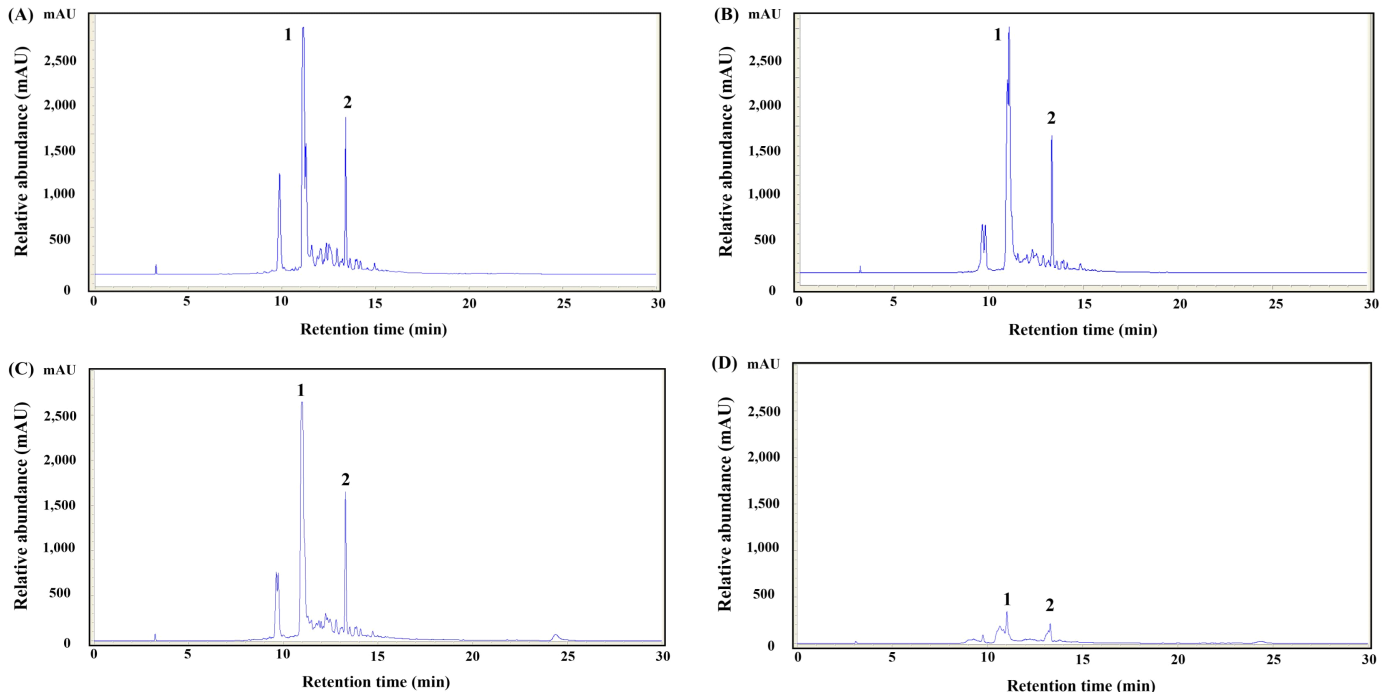

Fig. 1. Comparison of HPLC chromatogram of Dendropanax morbiferus extract according to ethanol concentration.

A, leaf-30\% fermented alcohol (2 h); B, leaf-50\% fermented alcohol $(2 \mathrm{~h})$; C, leaf- $70 \%$ fermented alcohol $(2 \mathrm{~h})$; D, leaf- $95 \%$ fermented alcohol $(2 \mathrm{~h})$. 
째 $\mathrm{CA}$ 와 RT 함량이 가장 높았으므로 본 연구 결과와도 일치 하였다.

\section{황칠나무 부위별 추출물의 항산화 활성 비교}

황칠 부위별(잎, 줄기, 뿌리) 열수 및 발효주정 추출물에 따른 항산화 활성 비교 결과는 Fig. 2에 나타내었다. DPPH 및 $\mathrm{ABTS}$ 라디칼 소거활성은 추출시간과 관련하여 활성에 변화가 있지는 않는 것으로 나타났다. 황칠 잎 열수추출 2시 간째 $\mathrm{DPPH}$ 라디칼 소거활성은 $62.33 \%$ 였고, 4시간째 추출물 에서는 $62.43 \%$ 로 동일하였다. $30 \%$ 발효주정 추출 시에도 마 찬가지로 추출 시간에 따른 활성 변화는 없었으며, 2 시간과 4시간째 각각 $60.05 \%$ 및 $61.86 \%$ 를 나타내었다. $50 \%$ 발효주 정 추출 시에는 열수와 $30 \%$ 발효주정 추출물에 비해 $51.29 \%$
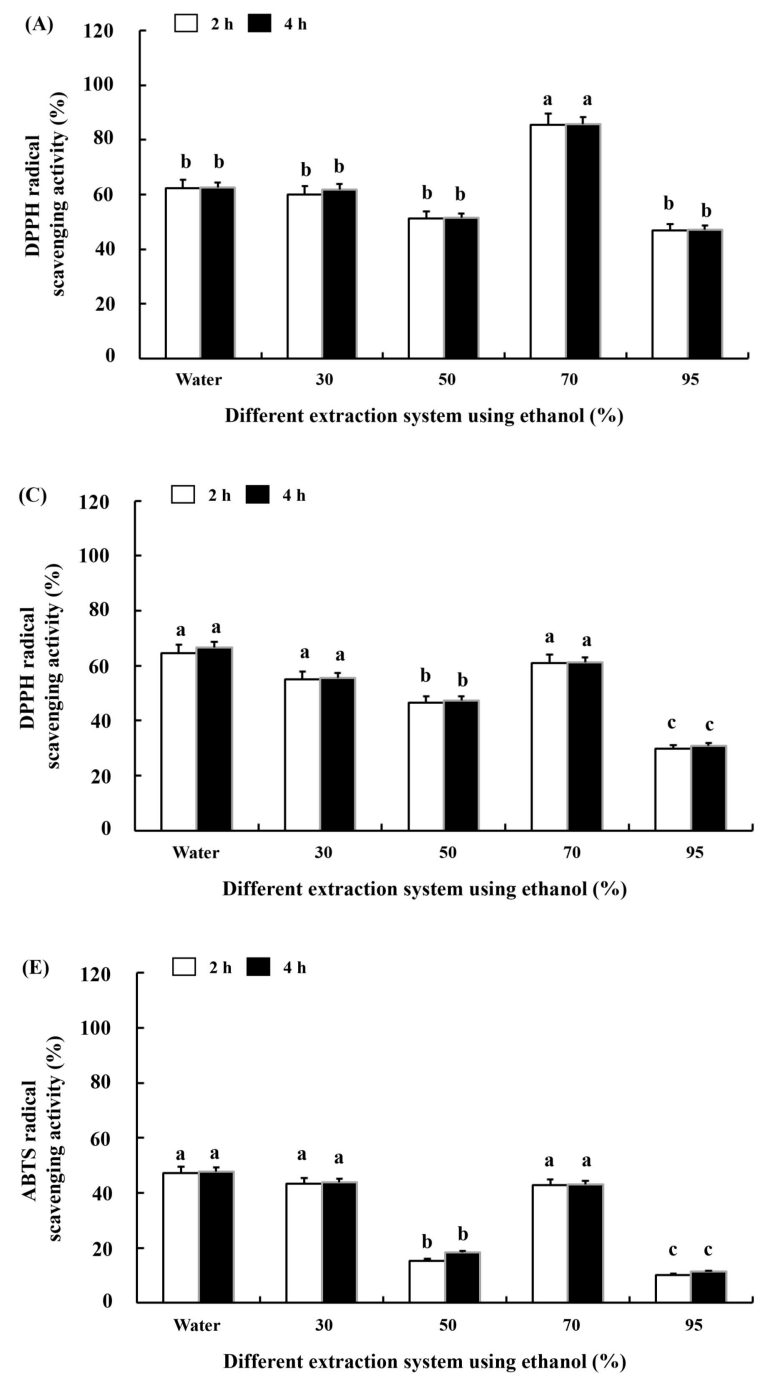

(2시간) 및 $51.48 \%$ (4시간)로 약간 감소하였다. $70 \%$ 발효 주 정 추출물에서는 $85 \%$ 로 가장 우수한 $\mathrm{DPPH}$ 라디칼 소거활 성을 보였다. $95 \%$ 발효주정 추출물은 $46.81 \%$ (2시간) 및 $47.14 \%$ (4시간)의 라디칼 소거활성을 보였다(Fig. 2A). 한편, $\mathrm{ABTS}$ 라디칼 소거활성 역시 $70 \%$ 주정 추출물(잎)에서 $110 \%$ 로 가장 높았다(Fig. 2D).

항산화 활성의 기작은 항산화 물질이 인체내에서 노화와 세포손상을 일으키는 free radical을 소거함으로써 산화를 방 지하는 것이다(Lee 등, 2015). 특히, Lee 등(2015)은 황칠나 무 잎 $70 \%$ 에탄올 추출물의 DPPH 라디칼 소거활성을 측정 한 결과, 추출물의 농도가 $5,1,0.5,0.1 \mathrm{mg} / \mathrm{mL}$ 일 때 각각 $89.8 \%, 76.4 \%, 44.7 \%, 19.1 \%$ 로 보고하였고, 농도 감소에 따 라 라디칼 소거활성이 감소하는 것으로 보고하였다. 이 결과
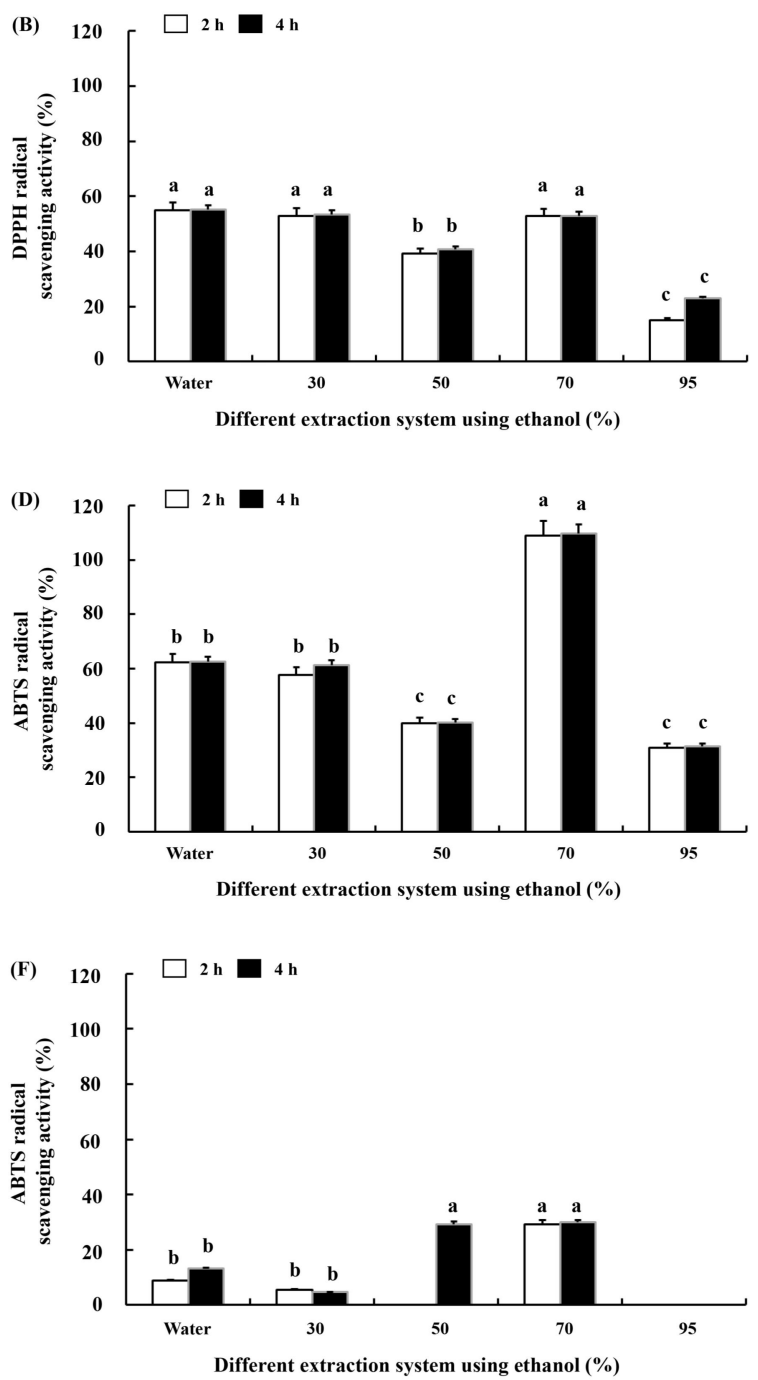

Fig. 2. Comparison of DPPH and ABTS radical scavenging activities of Dendropanax morbiferus extracts according to ethanol concentration. All values within a column with different superscript letters are significantly different from each other at $\mathrm{p}<0.05$ by Duncan's multiple range test. A, leaf; B, stem; C, root DPPH assay; D, leaf; E, stem; F, root ABTS assay. 
는 본 연구결과와 비교하였을 시 항산화 활성(\%) 수치는 서 로 다르게 나타났지만, 추출물의 농도와 측정방법 차이에 의 한 것이라 판단된다. 한편, 구실잣밤나무의 경우 사용한 추출 용매 종류에 따라 DPPH 라디칼 소거활성 차이가 있었고, 물 추출물이 가장 높았으며, 에탄올과 에틸아세테이트 등의 용 매의 경우 합성 항산화제(BHA)와 유사한 활성도를 나타냈다 고 $\operatorname{Kim}$ 등(2011)은 보고하였다. 이러한 차이는 식물 종류에 따른 차이가 가장 크다고 생각되며, 추출용매 종류와 추출방 법에 따라서도 항산화 활성 등의 효능은 각기 다른 양상을 나타내는 것으로 판단된다. 끝으로, 본 연구에서 제조된 황칠 나무(잎) 주정 추출물의 경우, $70 \%$ 발효주정 추출물에서 $\mathrm{CA}$ 및 RT 함량이 가장 많이 용출되었으므로 황칠나무 잎에서 $\mathrm{CA}$ 와 $\mathrm{RT}$ 최적 추출조건은 추출온도 $80^{\circ} \mathrm{C}$, 추출용매는 $70 \%$ 주정, 추출시간은 2 시간인 것으로 결론을 도출하였다.

\section{요 약}

본 연구에서는 황칠나무 부위별(잎과 줄기, 뿌리) 추출물 의 total phenolics(TP)와 phytochemicals 함량 및 라디칼 소 거 활성을 조사하였다. 부위별 모든 추출물의 chlorogenic $\operatorname{acid}(\mathrm{CA})$ 와 rutin(RT) 함량 및 라디칼 소거 활성은 잎 > 줄기 $>$ 뿌리 순이었다. 잎의 경우, TP 함량은 열수와 주정 추출 $(30-70 \%)$ 시 $2.15-2.52 \mathrm{mg} / \mathrm{g}$ 수준으로 상이한 용매 조건과 시간에 따른 차이는 없었으나, $95 \%$ 주정 추출물은 1.06 $\mathrm{mg} / \mathrm{g}$ (추출 시간: 2-4 h)으로 함량이 가장 낮았다. 특히, $70 \%$ 주정 2시간 추출물의 $\mathrm{CA}$ 와 RT 함량은 각각 $12.33 \mathrm{mg} / \mathrm{g}$ 및 $14.01 \mathrm{mg} / \mathrm{g}$ 으로 가장 높았고, 이에 상응하여 $\mathrm{DPPH}$ 와 $\mathrm{ABTS}$ 라디칼 소거활성은 $85 \%$ 및 $110 \%$ 로 가장 우수하였다.

\section{감사의 글}

본 연구는 중소벤처기업부에서 지원하는 '2019년 제품공 정개선기술개발사업(과제번호: S2792716)의 연구수행으로 인한 결과물임을 밝힙니다.

\section{Conflict of interests}

The authors declare no potential conflict of interest.

\section{ORCID}

Chung Eun Hwang

https://orcid.org/0000-0002-7130-1818

Kye Man Cho https://orcid.org/0000-0002-5928-0532

\section{References}

An NY, Kim JE, Hwang DY, Ryu HK. Anti-diabetic effects of aqueous and ethanol extract of Dendropanax morbifera Leveille in streptozotocin-induced diabetes model. Korean J Nutr Health, 47, 394-402 (2014)

Chae GC, Auh QS, Chun YH, Hong JP. Antibacterial activity of Artemisa capillaris THUNB on oral bacteria. J Oral Med Pain, 34, 169-177 (2009)

Chung SK, Jung JD, Cho SH. Antimicrobial activities of chopi (Zanthoxylum piperitum DC.) extract. J Korean Soc Food Sci Nutr, 28, 371-377 (1999)

Hwang CE, Cho KM, Kim SC, Joo OS. Change in physicochemical properties, phytoestrogen content, and antioxidant activity during lactic acid fermentation of soy powder milk obtained from colored small soybean. Korean J Food Preserv, 25, 696-705 (2018)

Hyun TK, Kim MO, Lee HK, Kim YJ, Kim EK, Kim JS. Evaluation of anti-oxidant and anti-cancer properties of Dendropanax morbifera Leveille. Food Chem, 141, 1947-1955 (2013)

Jang MR, Park HJ, Hong EY, Kim GH. Comparison of the antibacterial activity of domestic Cirsium japonicum collected from different regions. Korean J Food Cook Sci, 30, 278-283 (2014)

Kim SJ, Shin JY, Park YM, Chung KM, Lee JH, Kweon DH. Investigation of antimicrobial activity and stability of ethanol extracts of licorice root (Glycyrrhiza glabra). Korean J Food Sci Technol, 38, 241-248 (2006)

Kim JY, Yoon WJ, Yim EY, Park SY, Kim YJ, Song GP. Antioxidative and antimicrobial activities of Castanopsis cuspidata var. siebodii extract. Korean J Plant Res, 24, 200-207 (2011)

Lee CY, Yang MH, Moon JO. Antioxidant and hepatoprotective effects of the ethanol extract of Dendropanax morbifera Leveille on the $t$-butyl hydroperoxide-induced HepG2 cell damages. Kor J Pharmacogn, 50, $32-36$ (2019)

Lee SG, Lee SH, Park EJ. Antimicrobial and antioxidant activities of ethanol leaf extract of Dendropanax morbiferus Lev. Korean J Food Cook Sci, 31, 515-523 (2015)

Lim KP, Jung WY, Hong DH. Studies on the technical development of the traditional Korea golden varnish (Hwangchil) (III): main component analysis of Korea 
golden varnishes traditionally refined from the exudates of Dendropanax morbifera Lev. Mokchae Konghak, 26, 73-80 (1998)

Park BY, Min BS, Oh SR, Kim JH, Kim TJ, Kim DH, Bae $\mathrm{KH}$, Lee HK. Isolation and anticomplement activity of compounds from Dendropanax morbifera. J Ethnopharmacol, 90, 403-408 (2004)

Park YM, Han JS. A study on the utilization of Dendropanax morbifera Lev. leaf extract for material of functional cosmetics and hair growth products. Asian J
Beauty Cosmetol, 14, 277-288 (2016)

Yoo MY, Jung YJ, Yang JY. Antimicrobial activity of herb extracts. J Korean Soc Food Sci Nutr, 34, 1130-1135 (2005)

Yoon JS, Kim MS, Na HJ, Jung HR, Song CK, Kang SY, Kim JY. Screening test for Dendropanax morbifera Leveille extracts: In vitro comparison to ox-LDL-induced lipid accumulation, ethanol-induced fatty liver and HMG-CoA reductase inhibition. J Appl Biol Chem, 61, 1-8 (2018) 